\title{
PENERAPAN MODEL PEMBELAJARAN INQUIRI UNTUK MENINGKATKAN HASIL BELAJAR PADA MATA PELAJARAN ILMU PENGETAHUAN ALAM
}

(Studi ini dengan Pendekatan PenelitianTindakan Kelas Bagi Siswa Kelas IV Sekolah Dasar Negeri Citerep Kecamatan Walantaka Kota Serang)

\author{
Sastra Wijaya \\ STKIP Pelita Pratama \\ Sasatrawijaya0306@gmail.com
}

\begin{abstract}
Discussion of cycle I research results 1 meeting, from observations of the implementation of learning by using inquiry learning models in the first cycle of data. The first meeting obtained data that the observations on learning only reached 53.2, the results of observations on student activities 63, 87, and the level of mastery learning only reaching $24 \%$ with a class average value of 52 . From observations of the implementation of learning by using inquiry learning models in the first cycle the second meeting obtained data that the observations on learning have experienced an increase, namely with the acquisition of 71.6, the results of observations on student activities 67.6, and the level of student mastery only reaches $48 \%$ with a class average value of 59.2. From observations in this second cycle of learning, learning using Inquiry learning models has been going well and smoothly because all students with experience capital in learning the first cycle of meetings II and II and the guidance from the teacher, the students have learned as well as possible and in the second cycle there were no students who were noisy themselves. From learning with the Inquiry learning model in the second cycle of data obtained, that student learning activities have increased with a percentage of $78.67 \%$. With this data, it can be said that student learning activities have succeeded because they have achieved indicators of success. Then for student learning outcomes also increase, because the results of the evaluation given after learning is completed by telling students to work on the problems previously made by the teacher, respectively. each student gets good grades.
\end{abstract}

Keywords: Inquiry Learning, Learning Outcomes, Science

\section{ABSTRAK}

Pembahasan hasil penelitian siklus I pertemuan 1, Dari pengamatan pelaksanaan pembelajaran dengan menggunakan model pembelajaran Inkuiri pada siklus I Pertemuan pertama diperoleh data bahwa Hasil observasi pada pembelajaran hanya mencapai 53,2, hasil observasi pada aktifitas siswa 63, 87, dan tingkat ketuntasan belajar siswa hanya mencapai $24 \%$ dengan nilai rata-rata kelas sebesar 52. Dari pengamatan pelaksanaan pembelajaran dengan menggunakan model pembelajaran Inkuiri pada siklus I Pertemuan kedua diperoleh data bahwa 
Hasil observasi pada pembelajaran sudah mengalami peningkatan, yaitu dengan perolehan nilai 71,6, hasil observasi pada aktifitas siswa 67,6 , dan tingkat ketuntasan belajar siswa hanya mencapai $48 \%$ dengan nilai rata-rata kelas sebesar 59,2. Dari pengamatan pada pembelajaran siklus II ini, pembelajaran dengan menggunakan model pembelajaran Inkuiri sudah berjalan dengan baik dan lancar karena semua siswa dengan modal pengalaman pada pembelajaran siklus I pertemuan II dan II serta adanya bimbingan dari guru, maka para siswa sudah belajar dengan sebaik-baiknya dan pada siklus II ini sudah tidak ada siswa yang gaduh sendiri. Dari pembelajaran dengan model pembelajaran Inkuiri pada siklus II ini diperoleh data, bahwa aktivitas belajar siswa sudah meningkat dengan prosentase sebesar 78,67 \%. Dengan data ini dapat dikatakan aktivitas belajar siswa sudah berhasil karena sudah mencapai indikator keberhasilan. Kemudian untuk hasil belajar siswa juga mengalami peningkatan, karena hasil dari evaluasi yang diberikan setelah pembelajaran selesai dengan menyuruh siswa untuk mengerjakan soal-soal yang sebelumnya dibuat oleh guru, masing-masing siswa mendapatkan nilai yang bagus.

Kata Kunci : Pembelajaran Inkuiri, Hasil Belajar, IPA

\section{A. Pendahuluan}

Pendidikan adalah upaya strategis untuk membentuk watak dan karakteristik masyarakat yang harus memiliki keterampilan dasar, kemampuan untuk belajar sepanjang hayat, mengelola informasi, mengelola sumber daya, memecahkan masalah, mengambil keputusan, beradaptasi, berfikir kreatif, memotivasi diri, dan menyusun pertimbangan, serta kemampuan lainnya yang diperlukan untuk berinteraksi dengan alam lingkungannya.

Salah satu mata pelajaran yang memberikan kontribusi terhadap pembentukan watak dan karakteristik manusia adalah mata pelajaran IImu
Pengetahuan Alam (IPA). Pendidikan IPA menjadi wahana bagi siswa untuk mempelajari diri sendiri dan alam sekitar, serta prospek pengembangan lebih lanjut dalam menerapkannya dalam kehidupan sehari hari

Di tingkat Sekolah Dasar IPA diharapkan ada penekanan pembelajaran yang diterapkan mengarah pada pengalaman belajar siswa untuk merancang dan membuat suatu karya dengan cara pembuktian melalui penerapan konsep IPA dan kompetensi bekerja ilmiah secara bijaksana dalam aktivitas belajar.

Pembelajaran IPA di sekolah dasar harus mampu melibatkan siswa secara aktif dalam pembelajaran, 
memberikan kesempatan kepada siswa untuk mengembangkan dan menghubungkan pengetahuan yang telah mereka miliki dengan pengetahuan baru yang akan mereka pelajari.

Jika melihat kondisi nyata di lapangan. Pembelajaran IPA sebagian besar menggunakan strategi pembelajaran yang kurang bisa melibatkan siswa secara aktif di dalam pembelajaran.Pembelajaran bersifat transfer informasi dari guru kepada siswa, hanya sebagian siswa yang mampu terlibat langsung di dalam pembelajaran. Peran guru yang terlalu mendominasi pembelajaran menyebabkan anak tidak mampu mengembangkan pengetahuan awal yang dimiliki yang dapat meghubungkan materi pembelajaran yang akan dipelajari dengan kehidupan nyata anak. Berdasarkan pada tes akhir dalam pembelajaran Gaya, dari seluruh siswa yang berjumlah 25 orang, terdapat 9 siswa yang memperoleh nilai berada di bawah nilai batas lulus yang telah ditetapkan guru berdasarkan kriteria ketuntasan minimal, yang saat ini ditetapkan nilai 62.

Karakteristik IPA dalam KTSP di atas, maka proses pembelajaran di dalam kelas harus diselenggarakan secara "interaktif, inspiratif, menyenangkan, menantang, memotivasi siswa untuk berpartisipasi aktif, memberikan ruang gerak yang cukup bagi prakarsa, kreatifitas dan kemandirian sesuai dengan bakat, minat dan perkembangan pisik serta psikologi siswa.

Begitu pentingnya konsep dasar IPA diajarkan di SD yang mempunyai kegunaan dan kelebihan, karena dapat disajikan dalam pembelajarannya beranekaragam, sangat padat, ketat, tidak mendua arti, pasti tidak sama dan kebenarannya bersifat mutlak, maka kegunaan tersebut dianggap bermanfaat apabila para siswa telah memiliki sejumlah kemampuan konsep dasar IPA yang salah satunya adalah memahami konsep Gaya benda di kelas IV sekolah dasar.

Berdasarkan paparan di atas peneliti mengadakan penelitian tindakan kelas dengan judul "Meningkatkan Hasil Belajar Siswa dengan Menerapkan Model Pembelajaran Inkuiri dalam Mata Pelajaran IPA pada Pokok Bahasan Gaya Di Kelas IV SDN Citerep Kecamatan Walantaka Kota Serang yang merupakan sekolah unggulan". 
Model pembelajaran Inkuiri merupakan model pembelajaran yang penyajiannya

memberikan

kesempatan kepada siswa untuk menemukan informasi dengan atau tanpa bantuan guru. Sehingga guru dapat meningkatkan kompetensinya.

Adapun masalah yang teridentifikasi dilihat dari aktivitas siswa adalah

1. Apakah Siswa kurang aktif dalam proses pembelajaran karena siswa tidak terlibat langsung dalam pembelajarannya, siswa hanya melihat demonstrasi yang dilakukan oleh guru dan hanya mendengar penjelasan guru?

2. Apakah Dalam kegiatan kerja kelompok siswa kurang bekerjasama dalam percobaan hanya sebagian siswa yang aktif mengikuti kegiatan tersebut?

3. Apakah Pada akhir proses pembelajaran siswa cenderung tidak bisa menyimpulkan hasil pembelajaran?

4. Apakah Hasil belajar sebagian besar siswa yang dibawah nilai KKM yang telah ditetapkan oleh guru?

Adapun batasan masalah dalam penelitian ini yang sudah saya lakukan diantaranya adalah penerapan model
Inkuiri dalam mata pelajaran IPA pada materi gaya dan peneliti hanya meneliti pada aktivitas siswa dan hasil belajar siswa pada pembelajaran Gaya di kelas IV SDN Citerep Kecamatan Walantaka Kota Serang.

Berdasarkan latar belakang dan perumusan masalah, maka tujuan penelitian ini adalah untuk meningkatkan hasil belajar siswa dengan penerapan model pembelajaran Inkuiri dalammata pelajaran IPA pada Pokok Bahan Gaya di kelas IV SDN Citerep Kecamatan Walantaka Kota Serang Tahun pelajaran.

\section{B. Metode Penelitian}

Penelitian ini dilaksanakan dengan pendekatan penelitian tindakan kelas. Desain penelitian alur (siklus) PTK adalah desain penelitian siklus PTK secara konseptual.

Dalam penlitian ini, peneliti menggunakan sebuah metode deskriptif. Deskriptif merupakan paparan informasi tentang suatu gejala, pristiwa, kejadian sebagaimana adanya. Berbeda dengan penelitian eksperimen, pada penelitin deskriptif tidak diadakan perlakuan. Peneliti ini mengkaji dan memaparkan suatu keadaan 
sebagaimana adanya. Penelitan tindakan bukan lagi mengetes sebuah perlakuan, tetapi sudah mempunyai keyakinan akan ampuhnya suatu perlakuan. Peneliti disini langsung menerapkan perlakuan tersebut dengan hati-hat, seraya mengikuti proses serta dampak pelakuan yang dimaksud (Arikunto 2006: 56).

Penelitian pada satu kegiatan harus mencermati suatu objek dengan menggunakan cara aturan $\mathrm{dn}$ metodologi tertentu, untuk memperoleh data atau informasi yang bermanfaat dalam meningkatkan mutu suatu hal yang menarik minat dan penting bagi peneliti. Dalam penelitian ini berbentuk rangkaian siklus kegiatan siswa di kelas yang dalam waktu yang sama, menerima pelajaran yang sama dari guru yang sama (Arikunto 2006: 3).

Desain penelitian tindakan kelas untuk proposal menggunakan model Mc. Taggart Elliots yang terdiri dari empat tahap, yaitu :

Keterangan :

\section{Plan/Perencanaan}

Pada pelaksanaan tindakan dimulai dari proses identifikasi masalah yang kan diteliti. Setelah diuji kelayakan masalah yang akan diteliti, kemudian direncanakan tindakan selanjutnya.

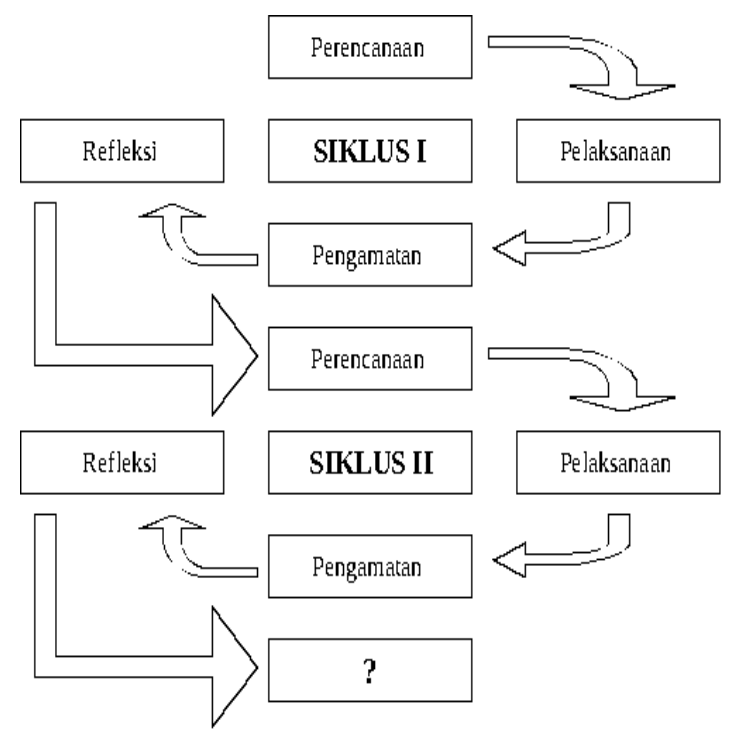

\section{Gambar 1}

Penelitian tindakan model Kemmis \& Targgart

(Suharsimi Arikunto, 2006 : 93)

2. Act/ Pelaksanaan

Pada pelaksanaan tindakan, perencanaan pelaksanaan tindakan dibantu oleh tim kolaborator.

3. Observasi

Observasi adalah pengamatan selama berlangsungnya kegiatan pembelajaran.

4. Reflecting/Refleksi

Refleksi adalah kegiatan mengulas atau mengulang materi yang baru saja dibahas/dipelajarai berdasarkan hasil refleksi, kolaborator dan guru menyimpulkan apakah tindakan yang dilakukan sudah dapat mencapai keberhasilan dari seluruh indikator yang ditentukan atau belum.

Prosedur Penelitian Tindakan Kelas. Berdasarkan rumusan masalah 
Pendas : Jurnal IImiah Pendidikan Dasar, ISSN Cetak : 2477-2143 ISSN Online : 2548-6950

Volume V Nomor 01, Juni 2020

dan metodologi penelitian yang telah diuraikan, maka selanjutnya akan diuraikan hasil analisis perencanaan, pelaksanaan, dan evaluasi penggunaan Model Inkuiri pada pembelajaran IPA melalui refleksi antara data yang diperoleh sebelum tindakan dengan data setelah pelaksanaan tindakan.

Pra-Penelitian dilakukan dengan mengumpulkan data obyektif sekolah dengan menggunakan form prapenelitian. Melakukan tes awal kepada siswa untuk mengetahui pemahamannya tentang materi pelajaran yang diberikan. Tes awal ini bertujuan untuk mengukur hasil yang diperoleh siswa sebelum pemberian tindakan.

Melakukan analisis data hasil tes awal. Hal ini bertujuan untuk mempermudah dalam merencanakan tindakan. Mencatat faktor-faktor penyebab terjadinya masalah dalam proses pembelajaran.

Penelitian Tindakan Siklus. perencanaan Tindakan dengan menyusun perangkat pembelajaran yang terdiri atas :

a. Silabus; mata pelajaran IPA Kelas IV, dengan standar kompetensi Memahami beragam sifat dan perubahan wujud benda serta berbagai cara penggunaan benda berdasarkan sifatnya.

b. Program Semester; kelas 1 Tahun pelajaran dengan materi ajar : Sifat berbagai wujud benda.

c. Rencana

Pelaksanaan

Pembelajaran (RPP); pembelajaran dengan menggunakan Model Inkuiri.

d. Bahan Ajar; Bahan ajarnya adalah penyesuaian Sifat berbagai wujud benda

e. Lembar Kerja Siswa; Bentuk LKS yaitu mengisi lembar kegiatan secara kelompok mengenai Sifat berbagai wujud benda

f. Media/Alat; Media yang digunakan adalah Gambar wujud benda padat dan cair.

Pelaksanaan Tindakan.

Peneliti melaksanakan proses pembelajaran atau penelitian yaitu melaksanakan perangkat pembelajaran sesuai dengan skenario penelitian.

Secara bersamaan kolaborator observer melakukan observasi dan penilaian terhadap pelaksanaan pembelajaran di kelas. Alternatif 1: kolaborator dapat melaksanakan observasi terhadap perilaku siswa dengan menggunakan lembar observasi siswa yang dipersiapkan. 
Alternatif 2: jika jumlah siswa terlalu banyak, dan dilakukan observasi siswa dalam waktu bersamaan, bisa menghasilkan data subyektif, sehingga lembar observasi dapat didesain/ disusun sedemikian untuk mengukur perubahan perilaku siswa, sehingga lembar observasi siswa dapat dibagikan kepada semua siswa, setelah pembelajaran selesai.

Observasi dilakukan secara simultan pada saat pembelajaran berlangsung. Kedua kolaborator menggunakan instrumen penilaian pelaksanaan pembelajaran di kelas. Peneliti melakukan observasi perubahan perilaku siswa dengan menggunakan lembar observasi perilaku siswa.

Refleksi dilakukan dengan merefleksi hasil evaluasi , apa saja yang sudah berhasil, dan dimana yang belum berhasil untuk dilanjutkan ke siklus berikutnya.

Teknik Pengumpulan Data

Teknik pengumpulan data dalam penelitian ini adalah berupa observasi, tes, wawancara dan studi dokumentasi.

a. Observasi

Penilaian pelaksanaan proses pembelajaran di kelas tim kolaborator yang terdiri dari 2 orang guru melakukan penilaian terhadap palaksanaan pambelajaran yang dilakukan oleh peneliti. Penilaian pelaksanaan pembelajaran dalam bentuk ceklis.

Perubahan perilaku siswa setelah dilakukan tindakan perbaikan. Observasi perilaku siswa dilakukan oleh tim kolaborator dengan mengamati perilaku siswa pada saat pembelajaran, terutama pada penggunaan Model Inkuiri.

b. Tes

Melaksanakan tes untuk mengukur ketercapaian indikatorindikator yang disampaikan oleh peneliti.

c. Wawancara

Melaksanakan wawancara bila diperlukan terhadap aspek-aspek yang diperdalam/penguatan data.

d. Studi Dokumentasi

Melakukan studi dokumentasi terhadap data-data yang dimiliki sekolah dan guru dengan data/fakta yang diperlukan dalam pemecahan masalah penelitian. Melakukan dokumentasi pada saat pembelajaran dilaksanakan.

Instrumen Pengumpulan Data

Instrumen yang digunakan dalam penelitian ini bertujuan untuk memperoleh data tentang peningkatan 
Pendas : Jurnal IImiah Pendidikan Dasar, ISSN Cetak : 2477-2143 ISSN Online : 2548-6950

Volume V Nomor 01, Juni 2020

hasil belajar siswa Kelas IV pada mata pelajaran IPA dengan menggunakan Model Inkuiri. Berdasarkan tujuan itu, maka ada tiga jenis instrument yang diperlukan, yaitu :

Analisa Data

Analisa data hasil penelitian skripsi berbasis penelitian tindakan kelas dengan statistik deskriptif yaitu analisis data sederhana melalui tahapan sebagai berikut :

Pengumpulan data

Dalam tahap ini peneliti mengumpulkan data yang diperoleh dari hasil penelitian pelaksanaan pembelajaran di kelas, observasi perubahan perilaku siswa, tes, dan wawancara. Reduksi Data,dalam tahap ini, peneliti memilih data yang relevan dan yang tidak relevan. Pemaparan Data, dalam tahap ini peneliti memaparkan/menyajikan data-data yang terseleksi dalam bentuk urutan jenis data.

Instrumen dalam Penilaiain

Pelaksanaan Proses Pembelajaran di kelas.

\section{Tabel 1}

Kisi-kisi Penilaian Pelaksanaan Pembelajaran di Kelas

\begin{tabular}{cccc}
\hline No & $\begin{array}{c}\text { Dimensi/As } \\
\text { pek }\end{array}$ & Indikator & $\begin{array}{c}\text { Nomor } \\
\text { Butir }\end{array}$ \\
\hline & Kegiatan & Kegiatan Awal & $1,2,3,4$ \\
\cline { 3 - 4 } 1 & Pembelajar & Kegiatan Inti & $5,6,7,8$ \\
\hline
\end{tabular}

\begin{tabular}{|c|c|c|c|}
\hline No & $\begin{array}{l}\text { Dimensi/As } \\
\text { pek }\end{array}$ & Indikator & $\begin{array}{l}\text { Nomor } \\
\text { Butir }\end{array}$ \\
\hline & an & & $\begin{array}{c}9, \\
10,11 \\
12\end{array}$ \\
\hline & & Kegiatan akhir & 13 \\
\hline \multirow{3}{*}{2} & \multirow{3}{*}{$\begin{array}{l}\text { Pemanfaat } \\
\text { an Media }\end{array}$} & $\begin{array}{l}\text { Menggunakan } \\
\text { buku yang } \\
\text { relevan }\end{array}$ & 14 \\
\hline & & $\begin{array}{l}\text { Menggunakan } \\
\text { kartu } \\
\text { pertanyaan }\end{array}$ & 15 \\
\hline & & $\begin{array}{l}\text { Menggunakan } \\
\text { kartu jawaban }\end{array}$ & 16 \\
\hline \multirow{3}{*}{3} & \multirow{3}{*}{$\begin{array}{l}\text { Pembelajar } \\
\text { an yang } \\
\text { memicu }\end{array}$} & $\begin{array}{l}\text { Menumbuhka } \\
\text { n partisipasi } \\
\text { aktif siswa }\end{array}$ & 17 \\
\hline & & $\begin{array}{l}\text { Menunjukkan } \\
\text { sikap terbuka }\end{array}$ & 18 \\
\hline & & $\begin{array}{l}\text { Menumbuhka } \\
\mathrm{n} \text { antusiasme } \\
\text { siswa }\end{array}$ & 19 \\
\hline 4 & $\begin{array}{c}\text { Penguasaa } \\
\text { n Bahasa }\end{array}$ & $\begin{array}{l}\text { Menggunakan } \\
\text { bahasa lisan } \\
\text { dan tulisan } \\
\text { dengan baik, } \\
\text { jelas, dan } \\
\text { benar }\end{array}$ & 20 \\
\hline \multirow[b]{2}{*}{5} & & $\begin{array}{l}\text { Menguasai } \\
\text { materi ajar }\end{array}$ & 21 \\
\hline & $\begin{array}{c}\text { Penguasaa } \\
\text { n Materi } \\
\text { Ajar }\end{array}$ & $\begin{array}{l}\text { Mengaitkan } \\
\text { materi dengan } \\
\text { dengan } \\
\text { kehidupan } \\
\text { sehari-hari }\end{array}$ & 22 \\
\hline \multirow[b]{2}{*}{6} & \multirow{2}{*}{$\begin{array}{l}\text { Evaluasi } \\
\text { dan } \\
\text { Pengendali } \\
\text { an }\end{array}$} & $\begin{array}{l}\text { Memantau } \\
\text { kemajuan } \\
\text { belajar selama } \\
\text { proses } \\
\text { pembelajaran }\end{array}$ & 23 \\
\hline & & $\begin{array}{l}\text { Dapat } \\
\text { memanajemen } \\
\text { waktu dengan } \\
\text { baik }\end{array}$ & 24 \\
\hline
\end{tabular}

Menutup

kegiatan

pembelajaran

25

dengan

kegiatan Do'a 
Pendas : Jurnal IImiah Pendidikan Dasar, ISSN Cetak : 2477-2143 ISSN Online : 2548-6950

Volume V Nomor 01, Juni 2020

C. Hasil Penelitian dan Pembahasan

1. Hasil Penelitian Siklus Pertemuan 1

Dari pengamatan pelaksanaan pembelajaran dengan menggunakan model pembelajaran Inkuiri pada siklus I Pertemuan pertama diperoleh data bahwa Hasil observasi pada pembelajaran hanya mencapai 53,2 , hasil observasi pada aktifitas siswa 63, 87, dan tingkat ketuntasan belajar siswa hanya mencapai $24 \%$ dengan nilai rata-rata kelas sebesar 52 . Rendahnya kualiatas pembelajaran pada siklus I pertemuan pertama diakibatkan karena:

Siswa belum terbiasa dengan suasana pembelajaran yang mengarah kepada pembelajaran metode inkuiri.

Masih ada kelompok yang belum bisa menyelesaikan tugas dengan waktu yang ditentukan. Hal ini karena anggota kelompok tersebut kurang serius dalam belajar. Masih ada kelompok yang kurang mampu mempresentasikan kegiatan.

Berdasarkan analisis data yang dilakukan oleh peneliti, dapat diketahui bahwa tingkat ketuntasan yang dicapai siswa Kelas IV SDN Citerep pada materi tersebut adalah sebesar $24 \%$ perolehan data tersebut dapat dilihat pada rekapitulasi nilai hasil belajar siswa siklus I pertemuan I sebagai berikut :

Tabel 2

Rekapitulasi Nilai Hasil Belajar Siswa Siklus I Pertemuan I

\begin{tabular}{cccc}
\hline Keberhasilan & $\begin{array}{c}\text { Jumlah } \\
\text { siswa }\end{array}$ & $\%$ & KKM \\
\hline Tuntas & 6 & 24 & 60 \\
\hline Belum Tuntas & 19 & 76 & 60 \\
\hline Jumlah & 25 & 100 & 120 \\
\hline Rata-rata & & 60 \\
\hline
\end{tabular}

Tabel di atas menunjukkan bahwa ketuntasan belajar siswa di Kelas IV sebesar 24\% dan yang belum tuntas sebesar $76 \%$, artinya ada $24 \%$ siswa belum berhasil melampaui Kriteria Ketuntasan Minimal (KKM). Maka hasil tersebut perlu ditingkatkan.

Tingkat ketuntasan belajar pada siklus I pertemuan I ini dipaparkan pada histogram berikut.

\section{Pembahasan Hasil Penelitian Siklus}

\section{Pertemuan 2}



Berdasarkan analisis data yang dilakukan oleh peneliti, dapat 
diketahui bahwa tingkat ketuntasan yang dicapai siswa Kelas IV SDN Citerep pada materi tersebut adalah sebesar $48 \%$ perolehan data tersebut dapat dilihat pada rekapitulasi nilai hasil belajar siswa siklus I pertemuan II sebagai berikut :

\section{Tabel 3}

\section{Rekapitulasi Nilai Hasil Belajar} Siswa Siklus I Pertemuan II

\begin{tabular}{lccc}
\hline Keberhasilan & $\begin{array}{c}\text { Jumlah } \\
\text { siswa }\end{array}$ & $\%$ & KKM \\
\hline Tuntas & 12 & 48 & 60 \\
\hline $\begin{array}{l}\text { Belum } \\
\text { Tuntas }\end{array}$ & 13 & 52 & 60 \\
\hline Jumlah & 25 & 100 & 120 \\
\hline \multicolumn{3}{c}{ Rata-rata } & 60 \\
\hline
\end{tabular}

Tabel di atas menunjukkan bahwa ketuntasan belajar siswa di Kelas IV sejumlah $48 \%$ dan yang belum tuntas sebesar 52 artinya belum berhasil melampaui Kriteria Ketuntasan Minimal (KKM). Maka hasil tersebut perlu ditingkatkan.

Tingkat ketuntasan belajar pada siklus I pertemuan II ini dipaparkan pada histogram berikut ini yang merupakan hasil dari pengolahan data pada bagian sebelumnya sehingga menghasilkan siklus yang lebih baik dari silus sebelumnya. Dari pengamatan pelaksanaan pembelajaran dengan menggunakan model pembelajaran

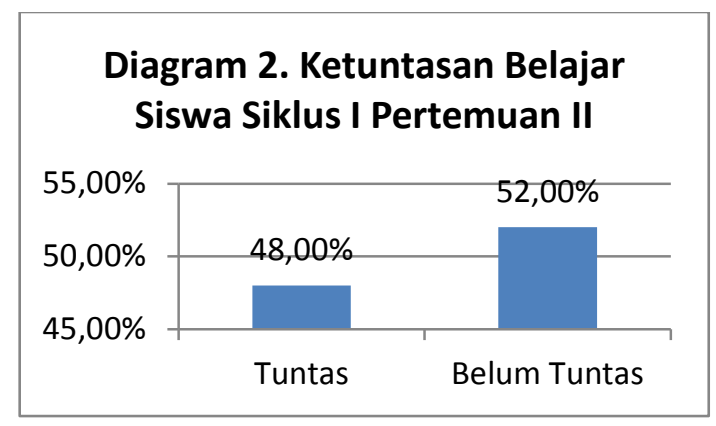

Inkuiri pada siklus I Pertemuan kedua diperoleh data bahwa Hasil observasi pada pembelajaran sudah mengalami peningkatan, yaitu dengan perolehan nilai 71,6 , hasil observasi pada aktifitas siswa 67,6, dan tingkat ketuntasan belajar siswa hanya mencapai $48 \%$ dengan nilai rata-rata kelas sebesar 59,2.

\section{Pembahasan Hasil Penelitian Siklus}

II

Berdasarkan hasil penelitian dari kedua observer terhadap pelaksanaan pembelajaran pada siklus II memperoleh nilai 82,8 . Untuk memperjelas data hasil siklus ini dapat dilihat pada tabel berikut ini:

Tabel 4

Rekapitulasi Data Hasil Penilaiain Pembelajaran Siklus II

\begin{tabular}{ccc}
\hline Observer & $\begin{array}{c}\text { Nilai } \\
\text { Akhir }\end{array}$ & Interpretasi \\
\hline I & 83,2 & Berkualitas \\
\hline II & 82,4 & Berkualitas \\
\hline Jumlah & 165,6 & Berkualitas \\
\hline Rata-rata & 82,8 & Berkualitas \\
\hline
\end{tabular}

Berdasarkan tabel di atas, pembelajaran IPA dengan 
Pendas : Jurnal IImiah Pendidikan Dasar, ISSN Cetak : 2477-2143 ISSN Online : 2548-6950

Volume V Nomor 01, Juni 2020

menggunakan model pembelajaran Inkuiri sangat berkualitas.

Data Hasil Observasi Aktivitas Siswa Siklus II

Penerapan model inkuiri yang difokuskan pada keaktifan siswa diukur melalui lembar observasi dalam bentuk kelompok belajar mengenai materi Sifat berbagai wujud benda. Pada siklus II semua siswa dalam kelompok yang telah ditentukan diberi tugas untuk mengisi soal essai. Berikut adalah tabel aktifitas belajar siswa

\section{Tabel 5}

Rekapitulasi Data Hasil Aktivitas Belajar Siswa Secara Berkelompok Siklus II

\begin{tabular}{lll}
\hline Observer & $\begin{array}{l}\text { Nilai } \\
\text { Akhir }\end{array}$ & Interpretasi \\
\hline I & 74,67 & Berkualitas \\
\hline II & 82,67 & Berkualitas \\
\hline Jumlah & 157,33 & Berkualitas \\
\hline Rata-rata & 78,67 & Berkualitas \\
\hline
\end{tabular}

Tabel di atas menunjukkan bahwa keaktifan belajar siswa dalam kelompok belajar sebesar 78,67 komposisi keaktifan belajar tiap kelompok sebagaimana pada tabel 4.19

Tabel 6 Data Hasil Aktifitas Belajar Siswa dalam Kelompok

\begin{tabular}{|c|c|c|c|c|}
\hline \multirow{2}{*}{ Kelompok } & \multicolumn{2}{|c|}{$\begin{array}{c}\text { Data Perolehan } \\
\text { Observer }\end{array}$} & \multirow{2}{*}{ Jumlah } & \multirow{2}{*}{$\begin{array}{l}\text { Rata } \\
\text {-rata }\end{array}$} \\
\hline & 1 & 2 & & \\
\hline 1 & 86,67 & 2,00 & 158,67 & $\begin{array}{c}79,3 \\
3\end{array}$ \\
\hline
\end{tabular}

\begin{tabular}{ccccc}
\hline Kelompok & \multicolumn{2}{c}{$\begin{array}{c}\text { Data Perolehan } \\
\text { Observer }\end{array}$} & Jumlah & $\begin{array}{c}\text { Rata } \\
\text { rata }\end{array}$ \\
\cline { 2 - 3 } & 1 & 2 & 152,00 & $\begin{array}{c}76,0 \\
0\end{array}$ \\
\hline 2 & 86,67 & 5,33 & 164,00 & $\begin{array}{c}82,0 \\
0\end{array}$ \\
\hline 3 & 86,67 & 7,33 & 153,33 & $\begin{array}{c}76,6 \\
7\end{array}$ \\
\hline 4 & 76,00 & 7,33 & 158,67 & $\begin{array}{c}79,3 \\
3\end{array}$ \\
\hline 5 & 77,33 & 1,33 & 786,67 & $\begin{array}{c}393 \\
33\end{array}$ \\
\hline Jumlah & 413,33 & 73,33 & 757,33 & $\begin{array}{c}78,6 \\
7\end{array}$ \\
\hline Rata-rata & 82,67 & 4,67 & 157 & menunjukkan
\end{tabular}

bahwa keaktifan belajar siswa sebesar 78,67 dengan kategori baik. Kelompok belajar yang paling aktif adalah kelompok 3 (82) di atas rata-rata, dan yang keaktifan yang paling rendah adalah kelompok 2 (76). Jadi keaktifan belajar siswa di bawah rata-rata adalah kelompok 14 , dan 5. Artinya diskusi dalam kelompok cukup aktif, dapat digambarkan dalam bentuk diagram di bawah ini.

\section{Diagram 3. Histogram Aktifitas Kelompok Belajar Siswa Siklus II}

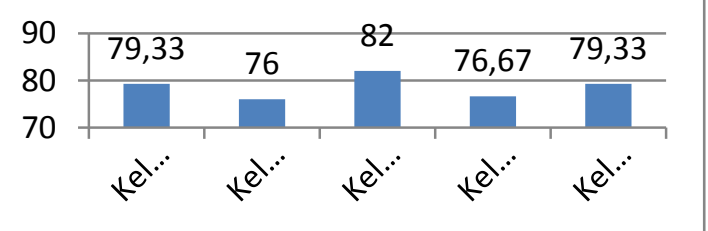

Data Hasil Belajar Siswa Siklus II

Berdasarkan analisis data yang dilakukan oleh peneliti, dapat diketahui bahwa tingkat ketuntasan yang dicapai siswa Kelas IV SDN Citerep pada materi tersebut adalah sebesar 75,20 perolehan data 
tersebut dapat dilihat pada rekapitulasi nilai hasil belajar siswa siklus II sebagai berikut :

\section{Tabel 7}

Rekapitulasi Nilai Hasil Belajar Siswa Siklus II

\begin{tabular}{|c|c|c|c|}
\hline Keberhasilan & $\begin{array}{c}\text { Jumlah } \\
\text { siswa }\end{array}$ & $\%$ & $\mathrm{KM}$ \\
\hline Tuntas & 25 & 100 & 60 \\
\hline $\begin{array}{l}\text { Belum } \\
\text { Tuntas }\end{array}$ & 0 & 0 & 60 \\
\hline Jumlah & 25 & 100 & 120 \\
\hline \multicolumn{3}{|c|}{ Rata-rata } & 60 \\
\hline
\end{tabular}

Tabel 4.20 menunjukkan bahwa ketuntasan belajar siswa di Kelas IV sejumlah $100 \%$ dan tidak ada yang tidak tuntas artinya belum berhasil melampaui Kriteria Ketuntasan Minimal (KKM). Maka hasil tersebut perlu ditingkatkan.

Tingkat ketuntasan belajar pada siklus I pertemuan I ini dipaparkan pada histogram berikut.

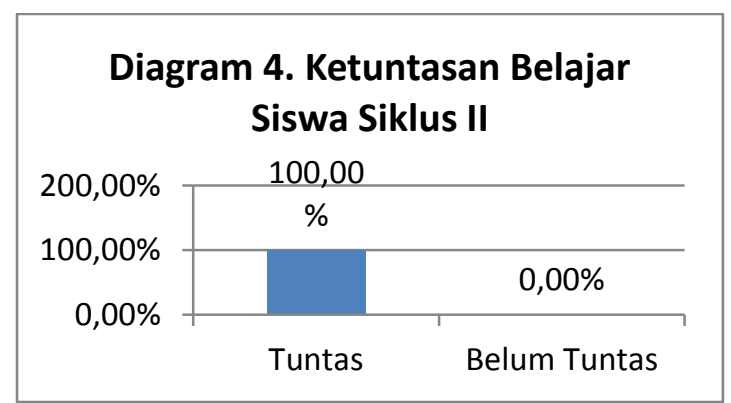

Pemahaman siswa dalam PBM sudah mengarah ke pembelajaran inquiry. Siswa mampu membangun kerjasama dalam kelompok untuk memahami tugas yang diberikan guru. Siswa mulai mampu berpartisipasi dalam kegiatan dan tepat waktu dalam melaksanakannya. Siswa mulai mampu mempresentasikan hasil kerja dengan baik. Meskipun nlai yang dicapai siswa masih jauh dari yang diharapkan.

Dari pengamatan pada pembelajaran siklus II ini, pembelajaran dengan menggunakan model pembelajaran Inkuiri sudah berjalan dengan baik dan lancar karena semua siswa dengan modal pengalaman pada pembelajaran siklus | pertemuan || dan I| serta adanya bimbingan dari guru, maka para siswa sudah belajar dengan sebaik-baiknya dan pada siklus II ini sudah tidak ada siswa yang gaduh sendiri.

Dari pembelajaran dengan model pembelajaran Inkuiri pada siklus II ini diperoleh data, bahwa aktivitas belajar siswa sudah meningkat dengan prosentase sebesar 78,67 \%. Dengan data ini dapat dikatakan aktivitas belajar siswa sudah berhasil karena sudah mencapai indikator keberhasilan Kemudian untuk hasil belajar siswa juga mengalami peningkatan, karena hasil dari evaluasi yang diberikan setelah pembelajaran selesai dengan menyuruh siswa untuk mengerjakan soal-soal yang sebelumnya dibuat 
oleh guru, masing-masing siswa mendapatkan nilai yang bagus.

\section{Kesimpulan}

Dari hasil penelitian dan analisis penelitian tentang peningkatan hasil belajar melalui model pembelajaran inquiri pada mata pelajaran IImu Pengetahuan Alam Studi dengan Pendekatan Penelitian Tindakan Kelas pada Siswa Kelas IV Sekolah Dasar Negeri Citerep Kecamatan Walantaka Kota Serang Tahun pelajaran. maka pada bab akhir skripsi ini dapat diambil kesimpulan sebagai berikut :

Penerapan metode inquiry adalah merupakan rangkaian kegiatan pembelajaran yang menekankan pada proses berfikir secara sistematis, kritis, logis dan analitis dalam merumuskan masalah dan menemukan jawaban, sehingga dapat meningkatkan pemahaman proses belajar mengajar mata pelajaran IPA.

Dimensi berpikir inquiry tentang materi pembelajaran sifat berbagai wujud benda dapat memotivasi siswa dalam belajar yang berdampak positif dalam pencapaian pemahaman belajar secara optimal dengan membangun sendiri pengetahuan, pemahaman, menemukan langkah- langkah dalam mencari penyelesian dari suatu materi yang harus dikuasai oleh siswa, baik secara individu maupun kelompok.

Penerapan

metode pembelajaran inquiry dapat meningkatkan pemahaman siswa tentang materi pembelajaran sifat berbagai wujud benda di kelas IV SDN Citerep Kecamatan Walantaka . Hal ini dibuktikan dengan hasil observasi pada aktifitas siswa pada siklus I pertemuan pertama yang hanya 53,87 menjadi 78,67 pada siklus II.

Dalam kegiatan belajar mengajar guru dapat meningkatkan kualitas pembelajaran yang menjadi tanggung jawabnya, dengan harapan menjadikan pembelajaran metode inquiry sebagai suatu alternatif dalam mata pelajaran IPA untuk meningkatkan pemahaman siswa, sehingga guru akan selalu mengikuti kemajuan ilmu pengetahuan dan teknologi. Sudah selayaknya guru membiasakan siswa untuk dapat belajar secara kelompok dalam rangka menumbuhkan sikap tenggang rasa dan kebersamaan seperti dalam kegiatan pembelajaran dalam model pembelajaran inkuiri. Keterbatasan waktu, biaya, dan tempat serta 
Pendas : Jurnal Ilmiah Pendidikan Dasar, ISSN Cetak : 2477-2143 ISSN Online : 2548-6950

Volume V Nomor 01, Juni 2020

pemilihan metode dalam meningkatkan motivasi belajar IPA dalam penelitian ini, sempga menjadi inspirasi untuk menggali lebih dalam lagi dengan mengadakan penelitian di tempat lain. Bagi semua praktisi pendidikan terutama para kaum elit pemegang kekuasaan pendidikan meningkatkan kualitas pendidikan dengan mementingkan kepentingan pendidikan di atas segalanya, karena pendidikan merupakan tonggak kehidupan bagi bangsa kedepan.

\section{DAFTAR PUSTAKA}

Asy'ari, Maslichah. (2009). Penerapan Pendekatan Sains Teknologi Masyarakat dalam Pembelajaran Sains di Sekolah Dasar. Yogyakarta: Universitas Sanata Darma.

Baharudin, $\mathrm{H}$ dan Esa $\mathrm{N}$. Wahyuni.(2009). Teori Belajar dan Pembelajaran. Jogjakarta: Arruz Media

Bundu Patta. (2008). Penelilaian Keterampilan Proses dan Sikap Ilmiah dalam Pembelajaran Sains-SD. Depdiknas: Dirjen PT. Direktorat Ketenagaan.

Hermawan, Ruswandi. dkk. (2009). Model Penelitian Pendidikan Sekolah Dasar. Bandung : UPI PRESS.

Herlina, E. (2008). Penerapan Pendekatan Interaktif dalam Pembelajaran Sains pada Materi Sumber Daya Alam. Skripsi pada
PGSD S1 Cibiru: Tidak diterbitkan.

Kasbolah, Kasihani. (2009). Penelitian

Tindakan Kelas (PTK).

Depdiknas: Dirjen PT. Proyek Pendidikan Guru Sekolah Dasar.

Moleong, Lexy J. (2008). Metodologi Penelitian Kualitatif. Bandung: Remaja Rosdakarya.

Munawarotun, Tia. (2009). Penggunaan Pendekatan Interaktif dalam Meningkatkan Hasil Belajar pada Pembelajaran Konsep Gaya. Skripsi pada PGSD S1 Cibiru: Tidak diterbitkan.

Samatowa, Usman. (2009). Bagaimana Membelajarkan IPA di Sekolah Dasar. Depdiknas: Dirjen PT. Direktorat Ketenagaan.

Sagala, Syaiful. (2009). Konsep dan Makna Pembelajaran. Bandung: Penerbit Alfabeta.

Sanjaya, Wina. (2009). Strategi Pembelajaran Berorientasi Standar Proses Pendidikan. Bandung: Kencana Prenada Media Group.

Slameto. (2009). Belajar dan Faktorfaktor yang Mempengaruhinya. Jakarta: Rineka Cipta.

Sumarga, Hadi. (2008). Pengaruh Eksperimen Sains Sederhana Terhadap Pemahaman Konsep Fisika Siswa. Skripsi pada FP MIFA Bandung:tidak diterbitkan.

Sutardi, Didi dan Sudirjo, Encep. (2008). Belajar Mandiri Pembaharuan Pembelajaran di $S D$. Bandung: UPI PRESS. 
Widodo, Ari, dkk. (2008). Pendidikan IPA di SD. Bahan Belajar Mandiri. Bandung: UPI PRESS.

Wiriaatmadja, Rochiati. (2010). Model Penelitian Tindakan Kelas. Bandung: Rosdakarya.

Wardhani, dkk. (2009). Pendidikan Tindakan Kelas. Jakarta: Universitas Terbuka. 